\author{
https://doi.org/10.52449/1857-4114.2020.35-1.11
}

CZU: 796.01:615.2

\title{
PEDAGOGICAL AND ORGANIZATIONAL ASPECTS IN THE FIGHT AGAINST DOPING IN SPORT
}

\author{
Triboi Vasile ${ }^{1}$, ORCID: 0000-0001-6562-340X \\ Nastas Natalia ${ }^{2}$, ORCID: 0000-0001-5555-1705 \\ ${ }^{1,2}$ State University of Physical Education and Sport, Chisinau, Republic of Moldova
}

\begin{abstract}
This paper addresses the problem of the use of prohibited steroids, used by some athletes to increase their performance. The legal framework of the Republic of Moldova and the international normative documents (WADA) were analyzed, defining the role of anti-doping measures, the information and education programs of the young athlete generation. The pedagogical and organizational aspects of the process of combating doping in sports were determined. There were also revealed some anti-doping activities, recommended for application in the system of children physical education and sports, as well as those for the youth from higher education of physical education and sports.

Keywords: pharmacology, load, anti-doping, anabolic steroids, recovery, disqualification, sanctions, state program.
\end{abstract}

\section{Introduction}

An important and very current problem of sport both in our country and in the world arena is the unauthorized use of drugs and the fight against them.

According to the decisions taken by the World Anti-Doping Agency (WADA), the International Olympic Committee (IOC), the National Olympic Committee and Sports of the Republic of Moldova (NOCS), under Moldovan law is strictly prohibited the use of anabolic substances by athletes. However, they resort to different methods of using pharmacological preparations in order to improve the level of physical training, endurance, ability to work, and the "contagion" with this addiction continues to affect new and new kinds of sports. The increased competition intensity, increased volume of systematic effort brings athletes to the limit of physical possibilities. As a result, ambitious athletes often seek additional energy sources. And this source of energy, to our great regret, is doping. The systematic use of anabolic preparations leads to a loss of stable results, and, consequently, to the increase of the required dose. Experts rightly point out that this flaw has spread throughout the world $[3,6,22,23]$.

In this context, an alarming situation was created in the performance sport, which led to the formation of structures capable of combating doping.

These organizations are: World AntiDoping Agency (WADA), Regional AntiDoping Organization (RADO) in Eastern Europe, National Anti-Doping Agency (NADA). Their function is to develop an antidoping control, namely to check whether the use of illicit drugs and pharmacological preparations by athletes is found. Unfortunately, the sports industry has started to actively cooperate with scientific research institutions in doping $[9,10,11,12,13,22$, 23].

The purpose of the research: to demonstrate based on the theoretical analysis, the opportunity to improve the anti-doping 
legislation in the Republic of Moldova, in order to combat the consumption of prohibited substances in sports.

\section{Methods and organization of research}

Doping was not a discovery of the twentieth century. The use of stimulant drugs began simultaneously with the development of competitions and continued with the development of sports in general. A great desire to defeat the opponent and become a winner at any price, even at the price of their own health - this is the essence of human nature. Consequently, athletes who practice different types of sports administer pharmacological preparations, which increase the efficiency of the body.

The term "doping" has its origin in English, meaning "drugging". About 20 years ago, cocaine and heroin were the first doping substances used by athletes, which had serious consequences because they were not prohibited by law. The use of doping substances or, in other words, drugs in sports, causing a short-term effect, has been attested since the 19 th century $[4,5,7,14-21]$.

The control over doping in sport appeared in 1968 at the Olympic Games in Mexico. Starting with the Sydney Olympics (2000), the athletes participating in the competitions took the oath for the first time to opt out of doping.

The former President of the IOC, Jacques Rogge, skeptically appreciated the prospects of solving the problem of doping in sport. He believed that the problem of doping in sports is impossible to solve, noting that doping is a form of criminality in sport that society cannot escape. In this respect, it will always be necessary to improve the control system on doping.

The legislation obliges international and national structures to improve the fight against doping and to tighten measures to combat this vicious phenomenon.

The IOC medical committee has identified a number of prohibited incentives. This list is constantly updated and supplemented with the latest drugs, and their use leads to immediate disqualification. The punishment lasts for few years, and in some cases, athletes can be disqualified for all life. Unfortunately, the victory over this scourge seems to be far away $[1,2,7,8,11,14,22]$.

Previously, controls on the use of doping substances were carried out only at international and national competitions. At these competitions, only highly qualified athletes, most often only champions and winners were subject to control. Today, the control is carried out at different stages of athletes training.

The fight against the use by sportsmen of the prohibited pharmacological preparations is not carried out by the competent bodies of the state, but by non-governmental organizations .

On November 16, 1989, in Strasbourg, members of the Council of Europe and other states signed Convention no. 135 against doping. This is a necessary measure, because the use of doping substances seriously affects the health of athletes and sports in general [2, 19, 20, 21, 22].

An important event related to the fight against doping was the adoption by the General Conference of UNESCO, at the 33rd session in Paris, on October 19, 2005, of the International Convention against Doping in Sport [11]. The signatory countries of this convention aim to protect the health, moral and physical condition of the athletes. This agreement, of major importance, contains the following influential measures:

- the national authorities are obliged to adjust the legislation of the country, which limits the availability of doping, transport, storage, import, distribution and sale, as well as the use of doping in sport;

- states are obliged to create a strict control over the use of doping in their territory, setting up anti-doping laboratories, which will be endowed with highly qualified specialists. These laboratories will implement research programs and methods, which will objectively demonstrate the negative influence of the 
prohibited pharmacological substances on the human organism;

- the application of sanctions, with the subsequent temporary disqualification of doped athletes, managers, coaches, doctors, physiotherapists and other complicit persons in violations of the anti-doping rules of WADA;

- the national agencies will inform annually all sports structures in their countries about the lists of pharmacological preparations prohibited by WADA;

- annuallyWADA, through the mass information sources, will publish the preparation lists of prohibited drug.

In order to solve this problem, the NADA has formulated a series of basic objectives:

- elaboration and realization, within the limits of the competence, of the national programs and plans of actions in preventing and combating at national level the phenomenon of doping; encouraging the practiceof a clean sport in order to protect the health of the athletes and to respect the principle of fair play in sports;

- promoting and supporting research on the phenomenon of doping in sport;

- collaboration with the central specialized bodies of the public administration, the National Olympic and Sports Committee and the sports structures regarding the elaboration and promotion of programs and plans related to the field;

- the management, elaboration and approval of the financing, as well as the exercise of control over the use of the financial means for carrying out the annual programs related to the Agency's field of activity;

- organizing and coordinating the implementation of policies in the areas of competence, ensuring uniform application of national and international legislation in the fields concerned;

- supporting scientific research in the field of preventing and combating the phenomenon of doping in sport;

- ensuring international collaboration in the field of preventing and combating doping in sports, by concluding and executing international agreements and treaties in the field;

- organizing and conducting, in accordance with the legislation in force, public procurement of goods, services and works for the needs related to the activity of the Agency;

- coordinating the activities of training, teaching and improving the staff in the field of activity;

- organizing seminars, conferences, thematic symposiums and establishing international collaboration relations in the spheres of activity;

- supporting and undertaking measures to boost the process of attracting foreign investments in the field;

- ensuring, observing and fulfilling the provisions of international agreements and treaties, legislative and normative acts in the field;

- applying and observing the procedures, within the limits provided by the international standards, completing the standard documents related to the activity of prevention and combating doping in sports;

- the exercise of other functions, according to the legislation in force [19].

Over the last few years, in our country, various anti-doping programs have been implemented. The NADA Government body from the Republic of Moldova effectively coordinates the implementation of different measures to combat the use of doping in the field of physical culture, especially in performance sports [11-21].

\section{Research results}

Programs to combat doping in sport, to protect health, are permanently in the spotlight of the Parliament and the Government of the Republic of Moldova, of the State University of Physical Education and Sport, of the National Olympic and Sports Committee, of the national sports federations in the country.

The Parliament of the Republic of Moldova has adopted the "Law for the prevention and combating of doping in sports" (no. 185 of 
11.07.2012), which aims to prevent and combat at national level the phenomenon of doping by adopting and implementing antidoping policies and regulations; encouraging the practice of a clean sport in order to protect the health of the athletes and to respect the principle of fair play in sports; promoting and supporting scientific research on the phenomenon of doping; promoting the state policy in the field of human health care and promoting a healthy way of life[19].

The Government of the Republic of Moldova has approved by Decision no. 960 of 17.11.2014, the establishment of the National Anti-Doping Agency (NADA), which is a public institution with legal personality, being in its subordination [19].

The NADA has the mission to ensure and support the achievement of the objectives of the Governance Program by developing, promoting and implementing policies in the fight with the use of doping in sport.

In November 2015, the National AntiDoping Agency developed and edited the Sportsman's Guide. This guide is intended to clarify the World Anti-Doping Code, and the basic objective is to prevent intentional or unintentional use of prohibited substances or methods, or to commit any other violation of anti-doping regulations.

The NADA organizes and conducts educational seminars, lessons, workshops for both athletes (performance athletes, national and / or international athletes, young athletes), as well as for the assistant staff of athletes (coaches, sports physicians, parents, managers of sports structures etc.) on different topics (general notions on doping, violation of antidoping regulations, list of prohibited substances and methods, consequences of doping - sanctions, health and social, taking the risk of consuming food supplements, doping control procedures, rights and responsibilities of the athletes and the assistant staff of the athletes, the management of the results, the exemptions for therapeutic use, the presentation of the information regarding the location, etc.). During the seminars, participants are informed about the procedures for conducting doping control (Table 1) [19].

The National Anti-Doping Agency, being in a scientific research collaboration with SUPES, developed a methodical guide entitled "Pharmacological substances in sport", authors: Artiom Jucov and Odetta Țigănaș, Phd in medicine, assoc. prof. at the Department of Sports Medicine SUPES. Later, this methodical guide was approved for editing by the SUPES Senate.

NADA, in agreement with the State University of Physical Education and Sport (SUPES), in 2020, will develop a methodical course for students of the faculties of Sport, Pedagogy and Kinetotherapy, on the dangers of doping in sport.

The Moldovan Anti-Doping Agency systematically organizes scientific-practical conferences, in different cities in the country, with the generic "Sports Medicine: Challenges and Perspectives". Participants in these forums are performance athletes from schools and sports clubs, coaches, Methodists, managers of sports structures in the country.

The SUPES Senate will request the permission of the Ministry of Education, Culture and Research of the Republic of Moldova to include the course "Fighting doping in sports", in different curricula of specialties within the university.

The National Anti-Doping Agency, with the SUPES faculty-teachers, organizes actions and events dedicated to promoting clean sport and fairplay, in accordance with both the principles of the International Convention against doping in sport of UNESCO and the principles of the World Anti-Doping Code. 
Table 1. Doping Test Procedure

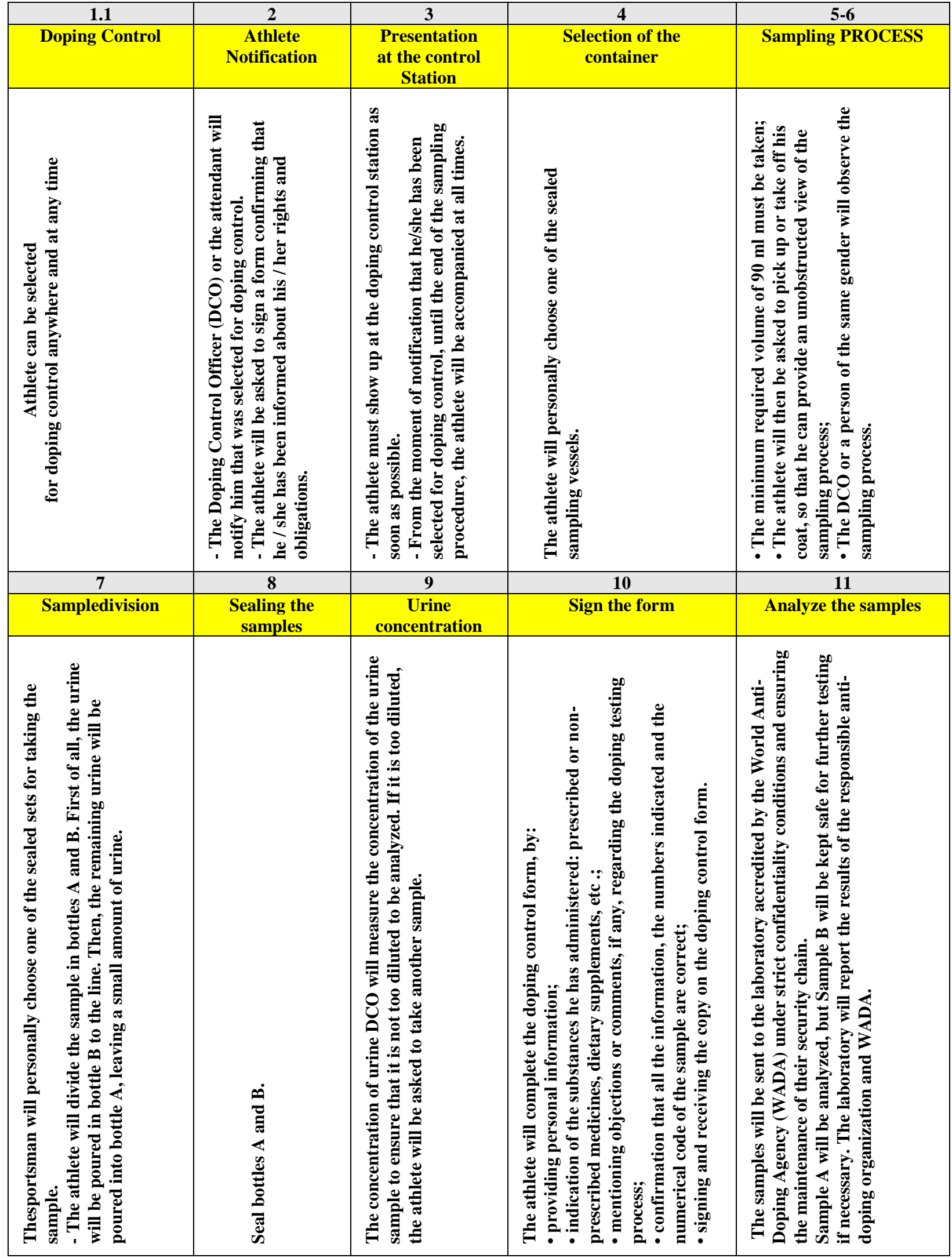


Methodical information is also placed on the website of the National Anti-Doping Agency, for example:

Platform ADeL. The Anti-Dopingplatform $e$-Learning(ADeL) offers access to all topics related to clean sports and anti-doping. It offers courses for athletes, coaches, doctors, administrators and anyone interested in learning more about anti-doping measures and the protection of clean sport values. It is available in English, French, Polish, Spanish.

The questionnaire "Play clean". The questionnaire "Play clean" is an interactive computer game, developed by the World AntiDoping Agency (WADA), which tests the knowledge in the field of anti-doping. The questionnaire is available in 36 languages, including in Romanian.

The challenge "Play clean". This is an online game for young people that challenge the decision-making skills of doping in sport (it targets young people under 19). The questionnaire is available in 36 languages, including Russian [19].

The structures in the country, empowered to fight against doping in sports, present, through different media sources, the most relevant aspects of anti-doping, violations of anti- doping regulations, the list of prohibited substances and methods, the negative effects of doping substances, but also the sanctions applied to athletes. In addition, the risks of administering drugs and dietary supplements, as well as the danger of unintentional violation of anti-doping regulations through the principle of strict liability, are highlighted. At the same time, a comprehensive description of the doping control procedure, the localization program, as well as the exemptions for therapeutic use is presented. During the events, the athletes as well as the coaches show an increased interest in the topics approached, addressing a lot of questions and suggestions $[1,2,3,4,8,10,16-18]$.

\section{Conclusions}

Summarizing the results of our study, we can conclude: doping causes irreparable damage to the health of a sportsman. Doping in sports kills the idea of fair and "clean" competitions, which is the basis of sport and the Olympic Movement. It is necessary to actively introduce in the process of preparation and competition a policy that encourages the moral principles of a fair sports competition, and every athlete, sports physicians and trainer must be aware of the deadly danger of doping.

\section{References:}

1. Budevici-Puiu L., Enache P., Budevici-Puiu A. (2004). Managementul educației fizice, legislație in sport. Elemente de drept. Iași: Altius Academy. 194 p.

2. Manolachi V. (2015). Optimization of phisical, tehical-tactical and psyhomotor abilities of judo players. In: „Gymnasium” Scientific Jurnal of Education, Sport and Health, No.1 Supplement, Vol XVI. Bacau, p.123-136.

3. Alekseyev S.V. (2013). Mezdunarodnoye sportivnoye pravo [International Sports Law]. Moscow: Zakon i pravo, publ. 895 p.

4. Soldatenkov F.N. (2010). Modern state of the anti-doping movement and its development with in the frame work of physical culture and sports education. In: Uchenye zapiski universiteta imeni P.F. Lesgafta, Vol. 60, No. 2, p. 112-116.

5. Triboi V. (2016). Problematica sportului ca activitate socială ce implică un management eficient. În: Congresul Științific Internațional „Sport, Olimpism, Sănătate”, 5-8- octombrie, Chişinău: Editura USEFS, p. 105-109.

6. Бусуйок С.Л., Побурный П.В., Браниште Г.С., Дорган В.П. (2019). Основы теории и методики спортивной тренировки. Кишинэу: Б.и., „Valinex”. 493 с. 


\section{ŞTIINŢA CULTURII FIZICE}

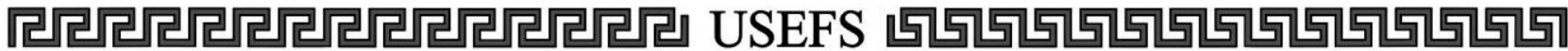

7. Бадрак К.А. (2011). Влияние экспериментальной антидопинговой образовательной программы на отношение молодежи к допингу, с учетом социально-педагогических факторов. В: Адаптивная физическая культура, № 2, с. 8-11.

8. Бадрак, К.А. (2011). Экспериментальная антидопинговая образовательная программа $и$ результаты ее внедрения (на примере молодых борияов). В: Паралимпийское движение в России на пути к Лондону: проблемы и решения: материалы Всероссийской научнопрактической конференции С.-Петерб. науч.-исследоват. ин-т физ. культуры. СПб., с. 5-7.

9. Платонов, В.Н. (2004). Система подготовки спортсменов в олимпийском спорте. Общая теория и ее практические приложения. К.: Олимпийская литература. 808 с.

10. Трибой В.Ю. (2005). К вопросу о физической культуре в вузе и развития студенческого спорта в Молдове: сочиологический аспект. В: Физкультура в школе, № 5. Киев, с.76.

11.www.wada-ama.org/en/resources/doping-control-process/doping-control-process-for-athletes

12.https://adel.wada-ama.org/

13.https://quiz.wada-ama.org/

14.http://ptchallenge.wada-ama.org/

15. http://www.consultant.ru/document/cons_doc_LAW_10699

16.http://www.consultant.ru/document/cons_doc_LAW_64829

17.http://www.consultant.ru/document/cons_doc_LAW_34661.

18.http://www.consult-ant.ru/document/cons_doc_LAW_28399

19.https://anad.gov.md/

20.https://anad.gov.md/sites/default/files/law/Regulamentul-agentiei-ro.pdf

21.https://anad.gov.md/sites/default/files/law/Lege-pentru-prevenirea-si\%20-combatereadopajului-in-sport-ro.pdf

22.https://olympic.md/

23.https://www.wada-ama.org/ 